\title{
Gambaran Histopatologik Hati Tikus Wistar yang Diberikan Sari Buah Naga Merah (Hylocereus polyrhisus) dan Parasetamol
}

\author{
${ }^{1}$ Maurin Wowor \\ ${ }^{2}$ Lily Loho \\ ${ }^{2}$ Poppy M. Lintong
}

\author{
${ }^{1}$ Program Studi Pendidikan Dokter Fakultas Kedokteran Universitas Sam Ratulangi Manado \\ ${ }^{2}$ Bagian Patologi Anatomi Fakultas Kedokteran Universitas Sam Ratulangi Manado \\ Email: wowor_maurin@yahoo.com
}

\begin{abstract}
Red dragon fruit contains natural antioxidant compounds in the form of lycopene, betalains, hydroxycinnamates, and flavonoids that allegedly can minimize liver cell damage due to hepatotoxic drugs such as paracetamol. This study was aimed to obtain histopathological features of liver tissue of Wistar rats given red dragon juice (Hylocereus polyrhisus) and paracetamol. This was an experimental laboratory study using 20 male Wistar rats as subjects. The dose of red dragon fruit juice was $7.8 \mathrm{~g} /$ day (single dose) and of paracetamol was $50 \mathrm{mg} /$ days (single dose); both were administered orally. Subjects were divided into 4 groups. Group A (negative control) was given no treatment for 7 days. Group B (positive control) was given paracetamol for 7 days. Group C was given red dragon fruit juice for 7 days and followed with administration of paracetamol for 7 days retaining the administration of red dragon fruit juice. Group D was administered with the red dragon juice and paracetamol simultaneously for 14 days. As the results, group A showed normal histological feature of liver cells. Group B showed fatty liver appearance. Group C showed regeneration of hepatocytes; fatty liver appearance was hardly found. Group D showed regeneration of hepatocytes and fatty liver appearance. Conclusion: Fatty liver could be induced by paracetamol. Administration of red dragon fruit juice for 7 days followed by red dragon fruit juice and paracetamol for 7 days showed better regeneration of hepatocytes than administration of paracetamol and red dragon juice simultaneously for 2 weeks.
\end{abstract}

Keywords: red dragon fruit, paracetamol, liver

\begin{abstract}
Abstrak: Buah naga merah mengandung senyawa antioksidan alami berupa likopen, betalains, hydroxycinnamates, dan flavonoid yang diduga dapat meminimalisasi kerusakan hepatosit yang antara lain disebabkan oleh obat-obatan berefek hepatotoksik seperti parasetamol. Penelitian ini bertujuan untuk mendapatkan gambaran histopatologik hepatosit tikus Wistar yang diberi sari buah naga merah (Hylocereus polyrhisus) dan parasetamol. Jenis penelitian ini eksperimental laboratorik, dengan menggunakan 20 ekor tikus Wistar. Pada penelitian ini digunakan sari buah naga merah 7,8 $\mathrm{g} / \mathrm{hari}$ (dosis tunggal) dan obat parasetamol $50 \mathrm{mg} / \mathrm{hari}$ (dosis tunggal) yang diberikan secara oral. Subjek penelitian dibagi menjadi 4 kelompok. Kelompok A (kontrol negatif) tidak diberi perlakuan selama 7 hari. Kelompok B (kontrol positif) diberikan parasetamol selama 7 hari. Kelompok $\mathrm{C}$ diberikan sari buah naga merah selama 14 hari dilanjutkan dengan pemberian parasetamol dan sari buah naga merah secara bersamaan. Kelompok D diberikan sari buah naga merah dan parasetamol secara bersamaan selama 14 hari. Sebagai hasil, kelompok A memperlihatkan gambaran histopatologik hepatosit normal. Pada kelompok B terlihat kerusakan hepatosit berupa perlemakan. Pada kelompok C tampak regenerasi hepatosit yang luas dan tidak ditemukan perlemakan sedangkan pada kelompok D tampak regenerasi hepatosit namun masih terdapat perlemakan hati. Simpulan: Pemberian parasetamol menyebabkan perlemakan hati. Pemberian sari buah naga merah selama 7 hari dilanjutkan dengan pemberian sari buah naga merah serta parasetamol selama 7 hari menunjukkan regenerasi hepatosit lebih luas dibandingkan dengan pemberian parasetamol dan sari buah naga merah secara bersamaan selama 2 minggu.
\end{abstract}

Kata kunci: buah naga merah, parasetamol, hati 
Hati adalah organ utama yang melakukan metabolisme dan detoksifikasi obat di dalam tubuh sehingga berpotensi mengalami kerusakan akibat beragam obat terapeutik dan lingkungan. ${ }^{1}$ Salah satu contoh obat yang berpotensi sebagai hepatotoksik yaitu parasetamol. ${ }^{2}$

Kandungan pada buah yang berfungsi sebagai hepatoprotektor ialah antioksidan. Buah naga merah yang dikenal dengan nama Pitaya, berasal dari Amerika Tengah dan Selatan dan dibawa ke Negara Asia Tenggara termasuk Indonesia. Senyawa antioksidan alami pada buah naga merah ini berupa likopen, betalains, hydroxycinnamates, dan flavonoid. ${ }^{3}$

Penelitian ini bertujuan untuk mengetahui pengaruh sari buah naga merah terhadap gambaran histopatologik hati tikus Wistar yang diinduksi parasetamol.

\section{METODE PENELITIAN}

Jenis penelitian ini ialah eksperimental laboratorik yang dilakukan pada bulan Agustus 2017 sampai Desember 2017 di Laboratorium Patologi Anatomi Fakultas Kedokteran Universitas Sam Ratulangi Manado.

Subjek penelitian ialah 20 ekor tikus Wistar spesies Rattus novergicus jantan dengan berat rerata 200 g. Sari buah naga merah yang digunakan dengan dosis 7,8 g/tikus/hari (dosis tunggal). ${ }^{4}$ Obat parasetamol yang digunakan ialah tablet 500 $\mathrm{mg}$ yang dijual bebas dengan dosis toksik $50 \mathrm{mg} /$ tikus/hari (dosis tunggal). ${ }^{5}$ Sari buah naga merah dan parasetamol dilarutkan menggunakan $1 \mathrm{ml}$ aquades lalu diberikan secara oral menggunakan sonde lambung khusus untuk tikus.

Subjek penelitian dibagi dalam 4 kelompok, yaitu satu kelompok kontrol negatif, satu kelompok positif, dan dua kelompok perlakuan. Kelompok A (kontrol negatif) tidak diberikan perlakuan selama 7 hari. Kelompok B (kontrol positif) diberikan parasetamol $50 \mathrm{mg} /$ hari dosis tunggal selama 7 hari. Kelompok $\mathrm{C}$ diberikan sari buah naga merah $7,8 \mathrm{~g} /$ tikus/hari dosis tunggal selama 7 hari dilanjutkan dengan pemberian parasetamol $50 \mathrm{mg} /$ hari dosis tunggal dan sari buah naga merah secara bersamaan selama 7 hari. Kelompok D diberikan sari buah naga merah 7,8 g/tikus/hari dosis tunggal dan parasetamol $50 \mathrm{mg} /$ hari dosis tunggal secara bersamaan selama 14 hari. Terminasi hewan uji dilakukan pada hari ke-8 dan hari ke-15 untuk mengambil organ hati. Organ hati diproses untuk pembuatan preparat histopatologik dan diamati dengan mikroskop cahaya.

\section{HASIL PENELITIAN \\ Kelompok A (kontrol negatif)}

Kelompok A ialah kelompok tikus Wistar yang tidak diberi perlakuan. Terminasi dilakukan pada hari ke-8. Gambaran mikroskopik hati tikus Wistar pada kelompok ini menunjukkan struktur dan susunan hepatosit yang normal (Gambar 1).

\section{Kelompok B}

Kelompok B ialah kelompok tikus Wistar yang diberi perlakuan parasetamol dosis toksik selama 14 hari. Pada kelompok ini tampak adanya perlemakan hati yang luas (Gambar 2).

\section{Kelompok C}

Kelompok C ialah kelompok tikus Wistar yang diberi sari buah naga merah saja selama 7 hari dilanjutkan dengan pemberian parasetamol dan sari buah naga merah secara bersamaan. Terminasi tikus dilakukan pada hari ke-15. Pada kelompok ini tampak adanya regenerasi yang ditandai dengan hepatosit berinti besar dengan nukleoli jelas, tersebar luas, dan tersusun beraturan (Gambar 3).

\section{Kelompok D}

Kelompok D ialah kelompok tikus Wistar yang diberi parasetamol dan sari buah naga merah secara bersamaan selama 14 hari. Terminasi tikus dilakukan pada hari ke-15. Pada kelompok ini tampak adanya regenerasi hepatosit, tetapi masih terdapat perlemakan hati (Gambar 4). 


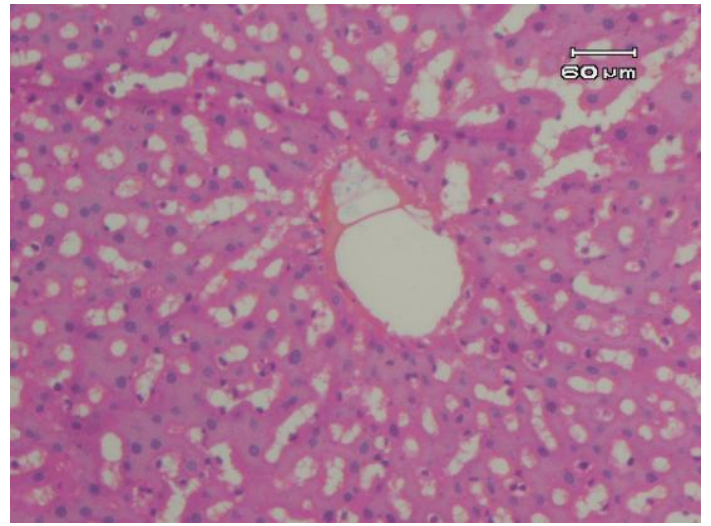

Gambar 1. Gambaran mikroskopik hati tikus Wistar kelompok A (kontrol negatif). Tampak gambaran hati normal, hepatosit tersusun radier, dengan sinusoid di antaranya (Pembesaran 400x)

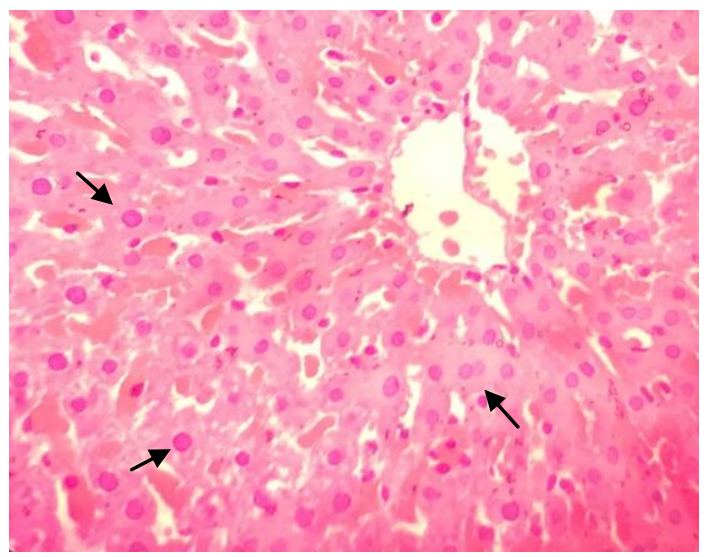

Gambar 3. Gambaran mikroskopik hati tikus kelompok C (perlakuan 1). Tampak gambaran hepatosit yang mengalami regenerasi pada hampir seluruh bagian jaringan; tidak ditemukan perlemakan. (Pembesaran 400x).

\section{BAHASAN}

Kerusakan hepatosit dapat disebabkan oleh berbagai faktor, diantaranya ialah penggunaan beberapa jenis obat secara terus-menerus dan tidak sesuai dengan dosis yang dianjurkan. Salah satu contoh obat yang berpotensi sebagai hepatotoksik ialah parasetamol. ${ }^{2}$ Penelitian yang dilakukan ini memberikan informasi mengenai gambaran histopatologik hati tikus Wistar yang diberikan parasetamol dan sari buah naga merah dengan membandingkan kelompok kontrol dan perlakuan.

Hasil penelitian menunjukkan terdapat perbedaan gambaran mikroskopik antara hati tikus Wistar kelompok kontrol negatif, kelompok kontrol positif, dan kelompok

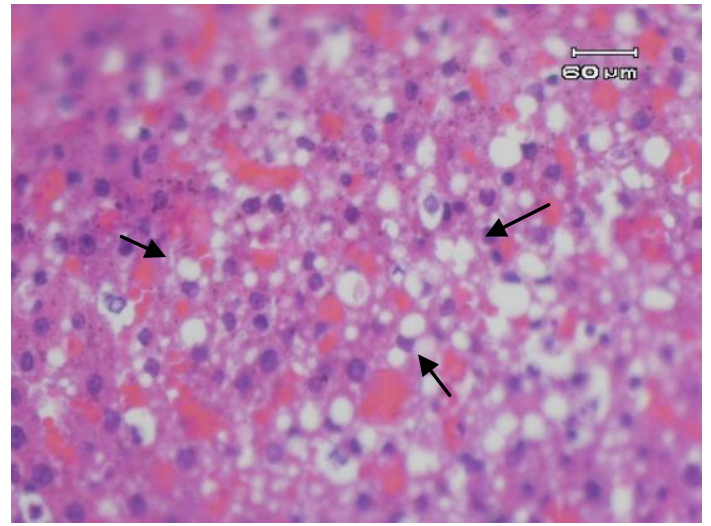

Gambar 2. Gambaran mikroskopik hati tikus kelompok B (kontrol positif). Tampak gambaran perlemakan hati (anak panah) (Pembesaran 400x).

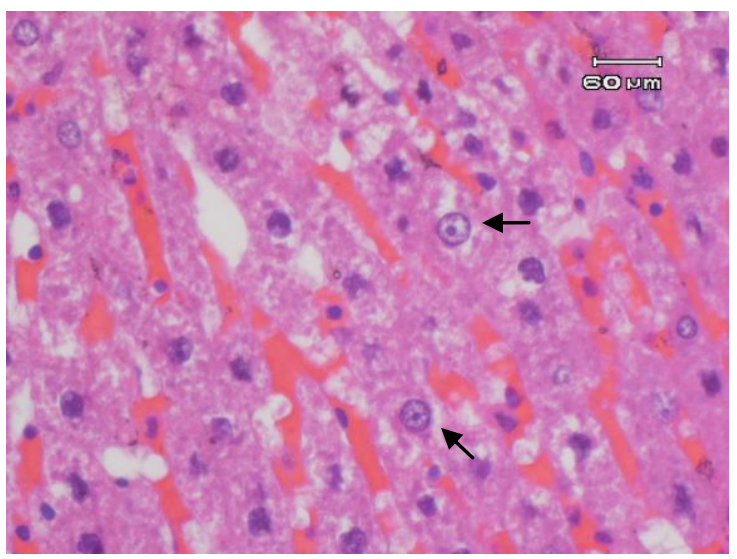

Gambar 4. Gambaran mikroskopik hati tikus kelompok D (perlakuan 2). Tampak gambaran hepatosit yang mengalami regenerasi dengan nukleoli jelas. Perlemakan hati masih tampak (Pembesaran 400x).

perlakuan (Gambar 1-4). Pada tikus Wistar kelompok kontrol negatif ditemukan gambaran morfologik hati normal. Perbedaan yang jelas terlihat antara hati tikus Wistar kelompok kontrol negatif (kelompok A) dan kelompok kontrol positif (kelompok B) yang diberi parasetamol selama 7 hari. Pada kelompok B jelas terlihat adanya perlemakan hati (Gambar 2). Perlemakan hati terjadi karena metabolisme parasetamol di dalam organ hati. Acetanilide dan phenacetin ialah produk dari parasetamol. Keduanya menjalani hidrolisis derivatif menghasilkan anilin yang dapat menyebabkan terjadinya methemoglobinemia dan anemia hemolitik. Jalur utama metabolisme untuk parasetamol ialah oleh O-konjugasi 
untuk menghasilkan O-sulfat konjugat terutama pada anak-anak dan O-glukuronida konjugat terutama pada orang dewasa. Parasetamol dan phenacetin juga mungkin mengalami metabolisme oksidatif melalui sitokrom P450 (CYP450) serta fungsi sistem oksidase untuk menghasilkan produkproduk $\mathrm{N}$-hydroxyamide yang reaktif dan dapat menurunkan molekul air untuk menghasilkan reaktif $\mathrm{N}$-acetylimidoquinone (NAPQI). Metabolit ini mengikat protein hati dan ginjal yang menyebabkan hepatotoksisitas dan nefrotoksisitas yang berhubungan dengan parasetamol dan phenacetin. Dalam kondisi normal $\mathrm{N}$-acetylimidoquinone reaktif ini dikonjugasi di hati dengan bantuan glutation yang kemudian dikeluarkan sebagai asam merkapturik atau konjugat sistein. 5

Dalam kasus overdosis parasetamol, glutation cadangan mungkin telah terpakai karena pembentukan konjugat. Pada kerusakan hati $>70 \%$, metabolit $\mathrm{N}$-acetylimidoquinone reaktif akan mulai bereaksi dengan kelompok nukleofilik thiol (-SH) yang terdapat pada protein hati dan ginjal membentuk covalent adducts yang menyebabkan nekrosis hepatik dan nekrosis tubulus ginjal. Overdosis parasetamol dapat menyebabkan nekrosis hati dan gagal ginjal yang berakhir dengan kematian.

Kelompok tikus Wistar yang diberi sari buah naga merah selama 7 hari dan dilanjutkan dengan pemberian parasetamol dan sari buah naga merah secara bersamaan selama 7 hari (kelompok C) menunjukkan adanya regenerasi sel dengan inti yang besar, sudah mulai teratur, dan tampak seperti sel normal. Perlemakan sel juga tidak terlihat pada kelompok C. Pada kelompok $\mathrm{D}$, diberikan parasetamol dan sari buah naga merah secara bersamaan selama 14 hari yang memiliki kesamaan dengan kelompok $\mathrm{C}$, yaitu adanya gambaran hepatosit yang mengalami regenerasi, tetapi masih ditemukan perlemakan hati. Efek likopen, betalains, hydroxylcinnamates, dan flavonoid dalam sari buah naga merah dapat mencegah kerusakan jaringan hati lebih lanjut akibat efek toksik parasetamol dan khasiatnya sebagai anti- oksidan dalam proses peroksidasi lipid dapat menghambat perlemakan hati. ${ }^{3,7,8}$

Gambaran histopatologik yang berbeda antar kelompok hewan uji pada penelitian ini menunjukkan adanya pengaruh pemberian sari buah naga merah dalam mencegah kerusakan hepatosit akibat efek toksik parasetamol serta menunjang terjadinya regenerasi hepatosit.

Limitasi penelitian ini ialah dalam hal bahasan farmakokinetik dan farmakodinamik sari buah naga merah karena referensi yang terkait masih terbatas. Demikian juga dengan jumlah regenerasi dan perlemakan sel tidak diukur secara kuantitatif.

\section{SIMPULAN}

Berdasarkan hasil penelitian ini dapat disimpulkan bahwa pemberian parasetamol menginduksi perlemakan hati. Pemberian sari buah naga merah selama 7 hari dilanjutkan dengan pemberian sari buah naga merah yang ditambahkan parasetamol selama 7 hari menunjukkan regenerasi sel hati lebih luas dibandingkan dengan pemberian parasetamol dan sari buah naga merah secara bersamaan selama 2 minggu.

\section{SARAN}

Disarankan untuk penelitian lanjut dengan penambahan jangka waktu perlakuan dan variasi dosis sari buah naga merah. Juga perlu dilakukan penghitungan secara kuantitatif jumlah sel-sel yang beregenerasi dan perlemakan hati.

\section{DAFTAR PUSTAKA}

1. Kumar, Cotran, Robbins. Buku Ajar Patologi Volume 2 (7th ed). Jakarta. EGC, 2007; p. 684-5.

2. Mishra SB, Pandey H, Pandey AC. Nanosuspension of Phyllanthus amarus extract for improving oral bioavailability and prevention of paracetamol induced hepatotoxicity in Sprague-Dawley rats. Adv Nat Sci: Nanosci Nanotechnol. 2013;4(3):2-3.

3. Zee F. Pitaya (Dragon Fruit, Stawberry Fruit). Hawai: College of Tropical Agricultural and Human Resource University of Hawai. F \& N; 2004. p.1-2. 
4. Ngatidjan. Metode Laboratorium dalam Toksikologi. Yogyakarta: Bagian Farmakologi dan Toksikologi Fakultas Kedokteran Universitas Gadjah Mada, 2012; p. 89.

5. Sidabutar D. Pengaruh ekstrak daun cengkeh terhadap gambaran histopatologi tikus Wistar yang diberikan parasetamol dosis toksik. eBm. 2016;4(1).

6. Borne RF. Nonsteroidal anti-inflammatory agents. In: Williams DA, Lemke TL, editors. Foye's Principles of Medicinal Chemistry (6th ed). Philadelphia:
Lippincott Williams \& Wilkins, 2007; p. 964-6.

7. Agustina S. Warna merah dalam buah naga punya kandungan antioksidan tinggi. Koran Tribun Travel, Januari, 2017; p. 3

8. Apak R, Guclu K, Demirata B, Ozyurek M, Celik SE, Bektasoglu B, et al. Comparative evaluation of various total antioxidant capacity assay applied to phenolic compounds with the CUPRAC assay. Molecules. 2007; 12(7):1496-547. 